\title{
Chlamydial screening of pregnant women in a sexually transmitted diseases clinic
}

\author{
B T GOH,* P MORGAN-CAPNER, + AND K S LIM* \\ From the *Department of Genitourinary Medicine, St Giles Hospital; and the +Department of Medical \\ Microbiology, King's College Hospital Medical School, London
}

SUMMARY Fifty-three consecutive pregnant women seen over six months were screened for chlamydial infection, syphilis, gonorrhoea, trichomoniasis, and candidosis. Chlamydia trachomatis was isolated in $20(37 \cdot 7 \%)$ patients, of whom six were sexual partners of known cases of non-gonococcal urethritis (NGU) (two had associated gonorrhoea or candidosis) and six had gonorrhoea (three had associated trichomoniasis and candidosis). If treatment is given to contacts of NGU 14 patients with other presenting conditions would not have been treated unless chlamydial cultures had been performed. This may lead to potentially serious complications of chlamydial infection in both mothers and neonates.

\section{Introduction}

Chlamydia trachomatis has been shown to be a potentially serious pathogen. In women sexually transmitted infection can lead to salpingitis. ${ }^{1}$ Furthermore, infection in pregnant women may lead to premature labour or stillbirth, neonatal death, and postpartum pelvic inflammation. ${ }^{2-4}$ In neonates infection is acquired during passage through the infected birth canal and can cause conjunctivitis with possible pannus formation and conjunctival scarring $^{3-10}$ as well as pneumonitis. ${ }^{11} 12$ The clinical criteria for the diagnosis of chlamydial genital infection in women are unsatisfactory and without culture many infected women would remain unrecognised and untreated. ${ }^{13-17}$ The purpose of this study was to assess the prevalence of chlamydial infection in pregnant women attending a clinic for sexually transmitted diseases (STD).

\section{Patients and methods}

\section{STUDY POPULATION}

Fifty-three pregnant women who attended consecutively the Alexanda Clinic, St Giles' Hospital, London, from June to December 1981 were screened for chlamydial infection, syphilis, gonorrhoea, trichomoniasis, and candidosis.

Address for reprints: Dr B T Goh, Whitechapel Clinic, The London Hospital, London El

Accepted for publication 25 May 1982
CHLAMYDIAL ISOLATION

Material for the culture of $C$ trachomatis was taken from the endocervix with a cotton swab (Exogen Ltd). Swabs were broken into bijoux bottles containing $3 \mathrm{ml}$ transport medium. The transport medium consisted of Eagle's minimal essential medium with $0 \cdot 13 \%$ sodium bicarbonate, $10 \%$ fetal calf serum, $0.5 \%$ glucose, and additional amino acids, vitamins, and glutamine. It contained gentamicin $(10 \mu \mathrm{g} / \mathrm{ml})$ and amphotericin $B(2 \cdot 5 \mu \mathrm{g} / \mathrm{ml})$. Specimens were kept at $4^{\circ} \mathrm{C}$ for a maximum of 18 hours before transport to the laboratory. On receipt in the laboratory specimens were stored at $4^{\circ} \mathrm{C}$ if inoculated on day of receipt or stored in liquid nitrogen if inoculation was to occur subsequently.

Isolation was performed in McCoy cells grown on 13-mm coverslips in culture tubes, each coverslip being seeded with $5 \times 10^{4}$ cells. The McCoy cells were seeded in growth medium (Eagle's minimal essential medium with $10 \%$ fetal calf serum, $0 \cdot 11 \%$ bicarbonate, $10 \mu \mathrm{g} / \mathrm{ml}$ gentamicin, and additional amino acids, vitamins, and glutamine) containing $25 \mu \mathrm{g} / \mathrm{ml}$ idoxuridine and were incubated for three days before use. This method is based on that described by Reeve et al. ${ }^{19}$ For isolation the growth medium was removed, replaced with $1 \mathrm{ml}$ of the specimen, and centrifuged at $3000 \times g$ for one hour. After further incubation for two hours at $35^{\circ} \mathrm{C}$ the supernatant was removed and replaced with fresh growth medium containing idoxuridine.

Tubes were incubated for a further 2-3 days before the coverslips were fixed with methanol and stained with iodine. C trachomatis was considered to be present if characteristic intracytoplasmic inclusions were seen. 


\section{Results}

The mean age of the 53 patients was 23.2 years (range 17-37 years.) Data with respect to race, marital state, parity, stage of pregnancy, and presence of symptoms in patients in whom $C$ trachomatis had been isolated is given in table I and the presenting diagnoses in table II. The overall chlamydial isolation rate was $20 / 53(37 \cdot 7 \%)$. The rate appeared to be higher in negroes, multipara, and in women in the second or third trimesters of their pregnancies; however, the differences were not significant (by the $\chi^{2}$ test with Yates's correction, $\mathrm{P}>0.05$ ).

TABLE I Distribution of patients with positive endocervical chlamydial culture results according to race, marital state, parity, stage of pregnancy, and presence of symptoms

\begin{tabular}{|c|c|c|}
\hline & $\begin{array}{l}\text { Total No of } \\
\text { patients }\end{array}$ & $\begin{array}{l}\text { No positive for } \\
\text { Chlamydia (\%) }\end{array}$ \\
\hline \multicolumn{3}{|l|}{ Race } \\
\hline Caucasians & 30 & $10(33)$ \\
\hline Negroes (West Indians) & 17 & $8(47)$ \\
\hline Afro-Asians & 6 & $2(33)$ \\
\hline \multicolumn{3}{|l|}{ Marital state } \\
\hline Single & 34 & $13(38)$ \\
\hline Married & 19 & $7(37)$ \\
\hline \multicolumn{3}{|l|}{ Parity } \\
\hline Primigravida & 36 & $12(33)$ \\
\hline Multipara & 17 & $8(47)$ \\
\hline \multicolumn{3}{|l|}{ Stage of pregnancy } \\
\hline First trimester & 17 & $4(24)$ \\
\hline Second trimester & 22 & $9(41)$ \\
\hline Third trimester & 14 & $7(50)$ \\
\hline \multicolumn{3}{|l|}{ Presence of symptoms } \\
\hline Asymptomatic & 19 & $6(32)$ \\
\hline Symptomatic & 34 & $14(41)$ \\
\hline
\end{tabular}

TABLE II Distribution of patients with positive endocervical chlamydial culture results according to presenting diagnoses at first visit

\begin{tabular}{lll}
\hline & $\begin{array}{l}\text { Total No } \\
\text { of } \\
\text { patients }\end{array}$ & $\begin{array}{l}\text { No positive } \\
\text { for } \\
\text { Chlamydia }\end{array}$ \\
\hline Presenting diagnoses at first visit & 6 & 4 \\
NGU contact & 1 & 1 \\
NGU contact + gonorrhoea & 1 & 1 \\
NGU contact + trichomoniasis & 1 & 0 \\
Gonorrhoea & 6 & 3 \\
Gonorrhoea + trichomoniasis & 5 & 2 \\
Gonorrhoea + trichomoniasis + & 3 & 1 \\
$\quad$ candidosis & 5 & 1 \\
Latent treponemal disease & & 3 \\
Latent treponemal disease + & 4 & 3 \\
candidosis & & 1 \\
Latent treponemal disease + & 1 & 1 \\
trichomoniasis & 8 & 1 \\
Candidosis & 2 & 0 \\
Trichomoniasis & 1 & 1 \\
Trichomoniasis + candidosis & 2 & 0 \\
Genital wart & 1 & 0 \\
Genital wart + candidosis & 1 & 0 \\
Urinary tract infection & 5 & \\
No infection & & \\
\hline
\end{tabular}

The clinical findings in pregnant women with either positive or negative chlamydial culture results were unhelpful in this study. All 20 Chlamydiapositive patients and Chlamydia-negative NGU contacts were treated with erythromycin stearate $500 \mathrm{mg}$ twice daily for two weeks. A chlamydial culture was repeated at the end of treatment in the 20 positive cases and 17 of their contacts were traced and treated. A further chlamydial culture was performed four weeks before the expected date of delivery in all patients.

\section{Discussion}

Since all contacts of NGU should be treated, ${ }^{18}$ chlamydial culture in this group will be of little practical importance. The isolation rate excluding this group, however, is still high $(14 / 44,31 \cdot 8 \%)$. This is in contrast to the isolation rate of $0-16 \%$ in pregnant women in non-STD clinics. ${ }^{920-24}$ In surveys carried out in STD clinics the isolation rates are $10-30 \%$ in unselected women, ${ }^{13-17} 25-2730-40 \%$ in women whose contacts have NGU, ${ }^{13-172526}$ and $2-17 \%$ in women whose contacts' histories are unknown. ${ }^{13} 152526$

In some American studies most infected patients were black and the higher prevalence in the black population is thought to reflect their lower socioeconomic status. ${ }^{1021}$ This would also apply to our patients who come from poor areas with $90 \%$ of the population belonging to social classes III, IV, and V and $10 \%$ of the population from overseas, mainly the West Indies.

The absence or presence of symptoms did not help in predicting chlamydial infection, as about one-third of Chlamydia-positive women had no symptoms. Furthermore, in symptomatic women most complained of a vaginal discharge, which could be physiological.

Martin et $a l^{2}$ estimated that there was about a 10 -fold increase in the relative risk of stillbirth and neonatal death after 20 weeks' gestation in Chlamydia-positive pregnant women. In our study one Chlamydia-positive patient who presented with genital warts had a mid-trimester abortion before treatment could begin. American studies show that in infants born to mothers with chlamydial infection of the cervix $60-70 \%$ subsequently acquire the infection, $10212220-50 \%$ develop inclusion conjunctivitis, ${ }^{1022} 23$ and $20 \%$ develop pneumonitis. ${ }^{21}$

Our results show a disturbingly high prevalence of chlamydial infection in pregnant women attending an STD clinic. In view of the high attack rate of chlamydial infection in neonates and the possible risk of stillbirth, premature labour, neonatal death, and postpartum pelvic inflammation pregnant women 
attending STD clinics should be screened for chlamydial infection. In an area in which most pregnant patients belong to the lower social classes a chlamydial culture facility is essential.

Most physicians would of fer treatment to contacts of NGU, and it has been proposed that patients with gonorrhoea should also be treated for concomitant chlamydial infection. 182829 This policy is not universally accepted, and in pregnant women the controversy is greater as drug treatment should be kept to a minimum. If a chlamydial culture service is available a rational approach can be made. One of our patients continued to have a positive chlamydial culture result despite two weeks' treatment with erythromycin. She denied having sexual intercourse during treatment. In view of possible persisting infection a repeat culture at the end of treatment is recommended. Alternatively, a higher dose of erythromycin may have to be considered, as absorption of erythromycin is known to be erratic and may be aggravated by the poor gastrointestinal motility during pregnancy. Four failures in 17 patients treated with erythromycin $500 \mathrm{mg}$ twice daily for 15 days was reported by Lassus et al..$^{30}$ As another patient had a positive chlamydial culture result only on the repeat test four weeks before the expected date of delivery, a final culture at that time should be performed for all patients who are at risk of acquiring a further infection.

Thus, a chlamydial culture service should be available to all STD clinics. Certain groups of patients are particularly at risk from infection, for example, those with gonorrhoea. Where facilities are limited, it is recommended that pregnant women, particularly those from the lower socioeconomic groups, should be screened routinely.

The demographic data on the Alexanda Clinic catchment area were kindly provided by the MRC Social Psychiatry Unit, Institute of Psychiatry, London. We would like to thank the staff of Alexanda Clinic, St Giles' Hospital and the Microbiology Department, King's College Hospital, for their help and cooperation; also $\mathrm{Mr}$ Alistair Clark, lecturer in quantitative methods, North London Polytechnic, for the statistical analysis.

\section{References}

1. Mårdh P-A, Ripa KT, Svensson L, Weström L. Chlamydia trachomatis infection in patients with acute salpingitis. NEngl J Med 1977; 296:1377-9.

2. Martin DH, Alexander ER, Eschenbach DA, et al. Prospective study of chlamydial infection in pregnancy. Abstract C3. In: Proceedings of Sexually Transmitted Diseases, 2nd meeting, Helsinki, Finland, 9-10 August 1979.

3. Dunlop EMC, Goldmeier D, Darougar S, Jones BR. Chlamydial infection of the genital tract in the mothers and fathers of babies suffering from ophthalmia neonatorum due to TRIC agent. In: Catterall RD, Nichol CS, (eds). Sexually Transmitted Diseases. London: Academic Press, 1976:83-8.
4. Rees E, Tait IA, Hobson D, et al. Neonatal conjunctivitis caused by Neisseria gonorrhoeae and Chlamydia trachomatis. Br J Vener Dis 1977;53:173-9.

5. Jones BR. Ocular syndromes of TRIC virus infection and their possible genital significance. Br J Vener Dis 1964;40:3-18.

6. Freedman $\mathbf{A}, \mathbf{A l}$-Hussaini MK, Dunlop EMC, et al. Infection by TRIC agent and other members of the Bedsonia group; with a note on Reiter's disease. Trans Ophthalmol Soc UK 1966;86: 313-20.

7. Dawson CR, Schachter J. TRIC agent infections of the eye and genital tract. Am J Ophthalmol 1967;63:1288-98.

8. Schachter J, Rose L, Meyer KF. The venereal nature of inclusion conjunctivitis. Am J Epidemiol 1967;85:445-52.

9. Forster RK, Dawson CR, Schachter J. Late follow-up of patients with neonatal inclusion conjunctivitis. $A m J$ Ophthalmol 1970;69:467-72.

10. Chandler JW, Alexander ER, Pheiffer TA, et al. Ophthalmia neonatorum associated with maternal chlamydial infections. Trans Am Acad Ophthalmol Otolaryngol 1977;83:302-8.

11. Beem MO, Saxon EM. Respiratory tract colonisation and a distinctive pneumonia syndrome in infants infected with Chlamydia trachomatis. N Engl J Med 1977;296:306-10.

12. Harrison HR, English MG, Lee CK, Alexander ER. Chlamydia trachomatis infant pneumonitis. Comparison with matched controls and other infant pneumonitis. N Engl J Med 1978; 298: 702-8.

13. Burns $\mathrm{DCMCD}$, Darougar $\mathrm{S}$, Thin $\mathrm{RN}$, et al. Isolation of chlamydia from women attending a clinic for sexually transmitted diseases. $\mathrm{Br} J$ Vener Dis 1975;51:314-8.

14. Nayyar KC, O'Neill JJ, Hambling MH, Waugh MA. Isolation of Chlamydia trachomatis from women attending a clinic for sexually transmitted diseases. Br J Vener Dis 1976; 52:396-8.

15. Richmond SJ, Paul ID, Taylor PK. Value and feasibility of screening women attending STD clinics for cervical chlamydial infections. Br J Vener Dis 1980;56:92-5.

16. Arya OP, Mallinson H, Goddard AD. Epidemiological and clinical correlates of chlamydial infection of the cervix. $\mathrm{Br} \mathrm{J}$ Vener Dis 1981;57:118-24.

17. Willcox JR, Fisk PJ, Barrow J, Barlow D. The need for a chlamydial culture service. Br J Vener Dis 1979;55:281-3.

18. Anonymous. Non-specific genital infection. $B r$ Med J 1979; ii: 161-2.

19. Reeve P, Owen J, Oriel JD. Laboratory procedures for the isolation of Chlamydia trachomatis from the human genital tract. J Clin Pathol 1975; 28:910-4.

20. Ross JM. Perinatal implications of lower genital tract flora. In: Perinatal Infections, (CIBA Foundation Symposium 77). Amsterdam, Oxford, New York: Excerpta Medica, 1980; 69-83.

21. Schachter J, Grossman M, Holt J, et al. Prospective study of chlamydial infection in neonates. Lancet 1979; ii:377-9.

22. Frommell GT, Rothenberg R, Wang SP, et al. Chlamydial infection of mothers and their infants. J Pediatr 1979;95: 28-32.

23. Alexander ER, Chandler J, Pheiffer TA, et al. Prospective study of perinatal Chlamydia trachomatis infection. In: Hobson D, Holmes KK (eds). Nongonococcal Urethritis and Related Infections. Washington DC: American Society for Microbiology, 1977; 148-52.

24. Mårdh P-A, Helin I, Bobeck S, et al. Colonisation of pregnant and puerperal women and neonates with Chlamydia trachomatis. Br J Vener Dis 1980;56:96-100.

25. Hilton AL, Richmond SJ, Milne JD, et al. Chlamydia $A$ in the female genital tract. Br J Vener Dis 1974;50:1-10.

26. Oriel JD, Powis PA, Reeve P, et al. Chlamydial infections of the cervix. Br J Vener Dis 1974; 50:11-6.

27. Woolfit JMG, Watt L. Chlamydial infection of the urogenital tract in promiscuous and non-promiscuous women. $\mathrm{Br} J$ Vener Dis 1977; 53:93-5.

28. Richmond SJ, Oriel JD. Recognition and management of genital chlamydial infection. $B r$ Med J 1978; ii: 480-3.

29. Willcox RR. Epidemiological importance of concealed nongonococcal urethritis. Br J Vener Dis 1979; 55: 149-53.

30. Lassus A, Paavonen J, Kousa M, Saikku P. Erythromycin and lymecycline treatment in chlamydia-positive and chlamydianegative non-gonococcal urethritis-a partner-controlled study. Acta Derm Venerol (Stockh) 1979; 59:278-81. 